\title{
Effect of Drying Methods on Value Added Duck Meat Balls
}

\author{
O. N. Bhaskar ${ }^{1 *}$, S. Biswas ${ }^{1}$, S. Bano ${ }^{2}$ and D. Bhattacharya ${ }^{3}$ \\ ${ }^{1}$ Department of Livestock Products Technology, Faculty of Veterinary and Animal Sciences \\ West Bengal University of Animal and Fishery Sciences, Kolkata-700037, West Bengal, India \\ ${ }^{2}$ Department of (Veterinary Medicine) Unit of L.F.C, Faculty of Veterinary and Animal \\ Sciences, Banaras Hindu University, U.P-231001, India \\ ${ }^{3}$ Department of Livestock Products Technology, Faculty of Veterinary and Animal Sciences \\ Banaras Hindu University, U.P-231001, India \\ *Corresponding author
}

\section{A B S T R A C T}

Present study was carried out to find the effect of different drying methods on value added duck meat balls. The study included the assessment of the quality parameters, sensory microbiological characteristic, storage stability and overall

\section{Keywords}

Duck meat, Phytoingredients, Drying, Quality parameters, Microbiological

Article Info

\section{Accepted:}

12 February 2020 Available Online: 10 March 2020 acceptability of dried duck meat balls stored under aerobic method of packaging at room temperature for one month amongst the consumers different parameters were studied, with the addition of certain Black eyed bean flour and phytoingredients, the products were prepared without influencing the organoleptic features. This product was dried in Solar and Mechanical dryer and the quality parameters, i.e. water activity, TBA value and the sensory evaluation and the microbiological characteristics i.e. Total Plate count, yeast and mould count were studied in 15 days interval. On analysis it was found that the differences between both the solar and mechanically dried products were almost similar in their physicchemical characteristics, sensory evaluation and the microbiological characteristics. However, after 60 days of storage under aerobic packaging method growth for yeast and mould have emerged on the meat balls. From the experiment it is concluded that dehydration or drying is probably one of the most effective meat preservation methods in the absence of a cold chain, in tropical countries with consumer acceptance.

\section{Introduction}

In India, duck constitute of $9 \%$ of total poultry population which is 17.8 million, of which 92\% are Deshi type (DADF, 2012). Duck occupies second place to chicken in our country. Ducks are mainly reared for laying purposes. Spent and culled ducks are mainly sold in the market after 3-4 lying years. Such duck meat intended for laying human consumption are less in juiciness, more toughness, less palatability which are the 
hidden reasons for non-acceptance of duck meat by consumers, though there is no significant decline in its nutritive value with increase in age (De, 2001). These drawbacks could be overcome by further processing of duck meat to different value added meat products. It can thus boosts up the socioeconomic status of thousands of rural poor duck raisers scattered in the villages of India.

The most common form of chemical deterioration of meat is oxidative rancidity. Lipid oxidation can have negative effects on quality of meat and meat products causing changes in sensory attributes (colour, texture, odour and flavour) and nutritional quality (Decker et al., 1996; Rababah et. al., 2004). To reduce lipid oxidation, antioxidants are used in meat and meat products. The antioxidants can be synthetic or natural in origin (Attmann et. al, 1986; Powell et al., 1986). But the demand and use for natural antioxidants, especially of plant origin has increased in the recent years due to the growing concern among the consumers about these synthetic antioxidants because of their potential toxicological effects (Juntachote et. al., 2006; Naveena et. al., 2008; Nunez de Gonzalez et al., (2008) Almost of the herbs and spices allow meat processors to develop novel meat products with enhanced nutritional and health benefits, improved shelf-life, quality of the products.

Some natural plant extracts contain flavonoids and phenolic compounds that have also antioxidative effects (Sekretar et al., 2004). Among the many preservation methods, dehydration or drying is probably one of the earliest and most effective methods (Hotchkiss and Potter, 1995). FAO (2001) reported that in the absence of a cold chain, dried meats can be kept for longer period in the developing tropical countries. It however, stated that the open air sun-drying process involves exposing meat to air and sunlight directly has a lot of disadvantages over ovendrying. Such exposed meat pieces to dust, rain, and insects would contribute to the unacceptability of meat owing to possible contaminations.

\section{Materials and Methods}

Indian Desi ducks were purchased from local market (Shyambazar Market, Kolkata). Ducks were subjected to ante-mortem inspection and maintained for $6 \mathrm{hrs}$ by giving water only. Slaughter and dressing was done in the Poultry Processing Unit as per the standard procedure of Sahoo and Panda (1983) after deboning meat was kept in the deep freezer ($20 \pm 2^{\circ} \mathrm{C}$ ) till it is processed for preparation of duck meat balls. Meat ball emulsion of each samples were prepared by using above mention formulation in bowl chopper (Stadler Ltd.) by adding non meat ingredients. The meat emulsion thus produced will be now used for preparation of uniformed sized meat balls mechanically. The aseptic measures were taken sufficiently within the laboratory. After preparation of meat balls they were placed in solar dryer as well as mechanical dryer. The identities of these groups were maintained and their weights were recorded: The temperature maintained in the mechanical dryer was $60^{\circ} \mathrm{C}$ but the temperature in solar dryer was $55-60^{\circ} \mathrm{C}$. The time allowed for meat balls, 40-45 hours in the solar dryer whereas in mechanical dryer the time allowed was 36-38 hours for meat balls. The capacity of the solar dryer is $1.5-2 \mathrm{~kg}$. The meat balls prepared using BEBF and phyto-ingradients are also placed for drying in above two methods.

\section{Quality traits study}

The quality parameters of the product were studied in dry form and soaked or rehydrated form. 


\section{Measurement of water activity $\left(a_{w}\right)$}

Water activity of the control as well as treated groups were measured by a water activity meter of Aqua Lab (Dew point water activity meter 4TE).

\section{Thiobarbituric acid value(TBA)}

Thiobarbituric acid values of samples were determined as per the procedure by Strange et. al. (1977) with slight modification.

\section{Microbiological studies}

Total bacterial count in the products was determined as per the method recommended in APHA (1984).

\section{Sensory evaluation}

Ready to eat dry meat products were subjected to evaluation for organoleptic qualities by serving the products to 8-member panel of semi trained judges of different age group and sexes. All the samples were evaluated for appearance, colour, flavour, texture, juiciness and overall acceptability by using a 8 point hedonic scale score card as described by Ingham et al., (2002).

\section{Statistical analysis}

All data which were obtained during the present investigation were analyzed in IBM, statically to draw valid conclusion in SPSS (Version 21.0) software, using general liner model for univariate data were analyzed by the statistical method as analyzed by ANOVA according to Tukey's HSD (Honest Significant Difference) Test (Tukey's, 1949). The results were expressed in term of mean and standard error (SE). A probability value of $(\mathrm{p}<0.05)$ was described a significant and $(p<0.01)$ was noted as highly significant.

\section{Results and Discussion}

Water activity percentage results were $0.6083 \pm 0.025$ and $0.6397 \pm 0.002$ for control and treatment groups respectively for solar dried meat balls at 0 days, and the same corresponding values were $0.6175 \pm 0.002$ and $0.6248 \pm 0.001$ for mechanical dried meat balls, whereas the values $0.7067 \pm 0.003$ and $0.7150 \pm 0.007$ for control and treatment groups for solar dried meat balls at 60 days, and the same values $0.7267 \pm 0.003$ and $0.7396 \pm 0.003$ were for mechanical dried meat balls in all the samples during storage periods which were kept in aerobic packaging. The treatment groups showed elevated water activity than control groups this might be due to increase moisture content during dry meat progressive storage periods. In dry product water activity findings showed no effect on water activity values of different drying techniques. The water activity of the product was significantly affected by the addition of BEBF and phyto-ingredients. Similar observation was also observed by Nam et. al (2016) in their study in sun- dried Venison Jerky.

TBA percentage results were $0.144 \pm 0.001$ and $0.105 \pm 0.001$ for control and treatment groups for solar dried meat balls at 0 days, and the same corresponding values were $0.154 \pm 0.001$ and $0.105 \pm 0.001$ for mechanical dried meat balls, whereas the values $0.379 \pm$ 0.005 and $0.217 \pm 0.007$ for control and treatment groups for solar dried meat balls at 60 days, and the same values $0.357 \pm 0.004$ and $0.199 \pm 0.002$ were for mechanical dried meat balls in all the samples during storage periods which were kept in aerobic packaging..

The growing trend of TBA values may be due to lipolysis occurring in the samples during the increased storage period. The values in control samples were greater than the treated 
groups, which may be due to the use of BEBF and phyto-ingredients in the treated groups, as these were the healthy sources of antioxidants. It showed that in the treated groups, the antioxidants may have counteracted lipolysis.

Oxidative rancidity is associated with air oxygen degradation and this increases the TBA values. At the same time Oxidation happens mainly with the fatty acids that are unsaturated. The duck meat products having a high content of fat come into contact with moisture of aerobic packaging along with air, resulting in oxidation during storage the results increased due to the above fact and the observation was in agreement with Bhattacharya et al., (2007), Kumar et al., (2017) and Biswas et al., (2007).

Mean \pm S.E values of total plate count (TPC) and Yeast and mould count of duck patties stored at ambient temperature for different storage periods are tabulated in Table 2. A significant $(\mathrm{P}<0.01)$ increase in TPC and Yeast and mould count values was noticed on 2nd day at ambient temperature. The findings on microbiological quality indicated that there was total presence of yeast and mould in the meat balls with permissible limit but in increasing trend through the study period. This growth of microbes might be due to higher moisture content during storage of the products and the greater water activity. Because the water activity of $0.6-0.7$ as observed in the presence study, favors in APHA (1984). In the present context when comparing these results as per BIS, the values were within the level of acceptance where from the meat products can be prescribed for human consumption.

Studies of sensory evaluation showed that in solar dried treatment groups, the general acceptability was more than that of mechanical dried treatment groups. Consumers preferred both the treatment groups of meat balls processed by drying techniques. There were no significant differences among the drying methods in spite of numerical differences of the values as observed. Waries (2006)) observed that cured dried solar products which were acceptable by the consumers. The present study also had the similar type of results and observation in dried meat product.

Table.1 Studies on the effect of drying methods on water activity $\left(\mathrm{a}_{\mathrm{w}}\right)$ and tba value on the shelflife of meat balls treated with bebf and phytoingredients (mean $\pm \mathrm{se}$ )

\begin{tabular}{|c|c|c|c|c|c|c|c|c|}
\hline \multicolumn{4}{c}{} & \multicolumn{4}{c|}{ WATER ACTIVITY (\%) } & \multicolumn{4}{c|}{ TBA VALUE (\%) } \\
\hline \multicolumn{4}{|c|}{ Solar dried } & \multicolumn{2}{|c|}{ Mechanical dried } & \multicolumn{2}{c|}{ Solar dried } & \multicolumn{2}{c|}{ Mechanical dried } \\
\hline Days & Control & Treatment & Control & Treatment & Control & Treatment & Control & Treatment \\
\hline & 0.6083 & 0.6397 & 0.6175 & 0.6248 & 0.144 & 0.105 & 0.154 & 0.105 \\
\hline $\mathbf{0}$ & $\pm 0.025^{\mathrm{c}}$ & $\pm 0.002^{\mathrm{c}}$ & $\pm 0.002^{\mathrm{e}}$ & $\pm 0.001^{\mathrm{e}}$ & $\pm 0.001^{\mathrm{e}}$ & $\pm 0.001^{\mathrm{e}}$ & $\pm 0.001^{\mathrm{e}}$ & $\pm 0.001^{\mathrm{e}}$ \\
\hline $\mathbf{1 5}$ & 0.6382 & 0.6486 & 0.6368 & 0.6452 & 0.195 & 0.128 & 0.209 & 0.125 \\
& $\pm 0.002^{\mathrm{bc}}$ & $\pm 0.004^{\mathrm{c}}$ & $\pm 0.002^{\mathrm{d}}$ & $\pm 0.004^{\mathrm{d}}$ & $\pm 0.001^{\mathrm{d}}$ & $\pm 0.001^{\mathrm{d}}$ & $\pm 0.002^{\mathrm{d}}$ & $\pm 0.001^{\mathrm{d}}$ \\
\hline $\mathbf{3 0}$ & 0.6688 & 0.6784 & 0.6538 & 0.6799 & 0.252 & 0.148 & 0.246 & 0.147 \\
& $\pm 0.002^{\mathrm{ab}}$ & $\pm 0.003^{\mathrm{b}}$ & $\pm 0.003^{\mathrm{c}}$ & $\pm 0.001^{\mathrm{c}}$ & $\pm 0.004^{\mathrm{c}}$ & $\pm 0.002^{\mathrm{c}}$ & $\pm 0.002^{\mathrm{c}}$ & $\pm 0.001^{\mathrm{c}}$ \\
\hline $\mathbf{4 5}$ & 0.6885 & 0.6957 & 0.6878 & 0.6970 & 0.326 & 0.179 & 0.294 & 0.167 \\
& $\pm 0.001^{\mathrm{a}}$ & $\pm 0.004^{\mathrm{a}}$ & $\pm 0.003^{\mathrm{b}}$ & $\pm 0.005^{\mathrm{b}}$ & $\pm 0.002^{\mathrm{b}}$ & $\pm 0.002^{\mathrm{b}}$ & $\pm 0.003^{\mathrm{b}}$ & $\pm 0.002^{\mathrm{b}}$ \\
\hline $\mathbf{6 0}$ & 0.7067 & 0.7150 & 0.7267 & 0.7396 & 0.379 & 0.217 & 0.357 & 0.199 \\
& $\pm 0.003^{\mathrm{a}}$ & $\pm 0.007^{\mathrm{a}}$ & $\pm 0.003^{\mathrm{a}}$ & $\pm 0.003^{\mathrm{a}}$ & $\pm 0.005^{\mathrm{a}}$ & $\pm 0.007^{\mathrm{a}}$ & $\pm 0.004^{\mathrm{a}}$ & $\pm 0.002^{\mathrm{a}}$ \\
\hline
\end{tabular}

Mean with diff. superscripts in the column and rows wise differ significantly, $(\mathrm{p}<0.01)$ 
Table.2 Effect of drying methods on microbiological qualities of meat ball treated with bebf and phytoingredients

\begin{tabular}{|c|c|c|c|c|c|c|c|c|}
\hline \multicolumn{5}{|c|}{ TPC (cfu/g) } & \multicolumn{4}{|c|}{ Yeast and Mould count ( $\mathrm{cfu} / \mathrm{g})$} \\
\hline \multicolumn{3}{|c|}{ Solar dried } & \multicolumn{2}{|c|}{ Mechanical dried } & \multicolumn{2}{|c|}{ Solar dried } & \multicolumn{2}{|c|}{ Mechanical dried } \\
\hline Days & Control & Treatment & Control & Treatment & Control & Treatment & Control & Treatment \\
\hline $\mathbf{0}$ & $\mathrm{e}_{\mathrm{e}}^{2.134 \pm 0.012}$ & $\underset{\mathrm{d}}{2.108 \pm 0.018}$ & $\underset{\mathrm{d}}{2.238 \pm 0.016}$ & $2.236 \pm 0.026$ & $\begin{array}{l}2.194 \pm 0 . \\
016^{\mathrm{e}}\end{array}$ & $\begin{array}{l}2.200 \pm 0 \\
.018^{\mathrm{d}}\end{array}$ & $\begin{array}{l}2.228 \pm \\
0.020^{\mathrm{d}}\end{array}$ & $\begin{array}{l}2.226 \pm 0.0 \\
29^{\mathrm{d}}\end{array}$ \\
\hline 15 & $\underset{d}{2.148 \pm 0.026}$ & $\underset{c}{2.146 \pm 0.028}$ & $\begin{array}{l}2.372 \pm 0.020 \\
\mathrm{c}\end{array}$ & ${\underset{c}{c}}^{2.378 \pm 0.024}$ & $\begin{array}{l}2.242 \pm 0 . \\
026^{\mathrm{d}}\end{array}$ & $\begin{array}{l}2.246 \pm 0 \\
.021^{\mathrm{c}}\end{array}$ & $\begin{array}{l}2.382 \pm \\
0.021^{c}\end{array}$ & $\begin{array}{l}2.368 \pm 0.0 \\
22^{\mathrm{c}}\end{array}$ \\
\hline 30 & ${ }_{c}^{2.234 \pm} \pm 0.010$ & $2.408 \pm 0.008$ & $2.438 \pm 0.010$ & $2.436 \pm 0.006$ & $\begin{array}{l}2.394 \pm 0 . \\
010^{c}\end{array}$ & $\begin{array}{l}2.400 \pm 0 \\
.008^{b}\end{array}$ & $\begin{array}{l}2.428 \pm \\
0.010^{\mathrm{b}}\end{array}$ & $\begin{array}{l}2.426 \pm 0.0 \\
09^{b}\end{array}$ \\
\hline 45 & $2.448 \pm 0.016$ & $\underset{\mathrm{ab}}{2.446 \pm 0.018}$ & $\underset{\mathrm{ab}}{2.472 \pm 0.010}$ & $\underset{\mathrm{ab}}{2.478 \pm 0.014}$ & $\begin{array}{l}2.442 \pm 0 . \\
016^{\mathrm{b}}\end{array}$ & $\begin{array}{l}2.446 \pm 0 \\
.011^{\mathrm{ab}}\end{array}$ & $\begin{array}{l}2.482 \pm \\
0.010^{\mathrm{ab}}\end{array}$ & $\begin{array}{l}2.468 \pm 0.0 \\
12^{\mathrm{ab}}\end{array}$ \\
\hline 60 & $2.502 \pm 0.017$ & $2.488 \pm 0.012$ & $2.548 \pm 0.012$ & $\underset{\mathrm{a}}{2.528 \pm 0.011}$ & $\begin{array}{l}2.500 \pm 0 \\
017^{\mathrm{a}}\end{array}$ & $\begin{array}{l}2.488 \pm 0 \\
.011^{\mathrm{a}}\end{array}$ & $\begin{array}{l}2.538 \pm \\
0.008^{\mathrm{a}}\end{array}$ & $\begin{array}{l}2.518 \pm 0.0 \\
14^{\mathrm{a}}\end{array}$ \\
\hline
\end{tabular}

Mean having different superscript column wise differ at 5\% level $(\mathrm{p}<0.05)$

Table.3 Sensory Evaluations Of Dried Duck Meat Balls

\begin{tabular}{|l|l|l|l|l|l|}
\hline \multicolumn{7}{|c|}{$\begin{array}{c}\text { Mean } \\
\text { Treatment } \\
\text { Group }\end{array}$} & Appearance & Flavour & Juiciness & Tenderness & $\begin{array}{l}\text { Overall } \\
\text { Acceptability }\end{array}$ \\
\hline A & $5.201 \pm 0.23^{\mathrm{b}}$ & $5.235 \pm 0.18^{\mathrm{b}}$ & $5.103 \pm 0.19^{\mathrm{a}}$ & $5.193 \pm 0.20^{\mathrm{a}}$ & $5.198 \pm 0.21^{\mathrm{a}}$ \\
\hline B & $6.248 \pm 0.16^{\mathrm{a}}$ & $6.101 \pm 0.21^{\mathrm{a}}$ & $5.146 \pm 0.19^{\mathrm{a}}$ & $5.196 \pm 0.20^{\mathrm{a}}$ & $5.203 \pm 0.20^{\mathrm{a}}$ \\
\hline C & $5.198 \pm 0.21^{\mathrm{b}}$ & $5.156 \pm 0.21^{\mathrm{b}}$ & $5.118 \pm 0.22^{\mathrm{a}}$ & $5.098 \pm 0.22^{\mathrm{a}}$ & $5.146 \pm 0.19^{\mathrm{a}}$ \\
\hline D & $6.117 \pm 0.10^{\mathrm{a}}$ & $6.048 \pm 0.07^{\mathrm{a}}$ & $5.141 \pm 0.24^{\mathrm{a}}$ & $5.151 \pm 0.21^{\mathrm{a}}$ & $3.188 \pm 0.21^{\mathrm{a}}$ \\
\hline
\end{tabular}

Different superscript column and rows wise differ at 5\% level $(\mathrm{p}<0.05)$ (A Solar Dried Control, B Solar Dried treatment, $\mathrm{C}=$ Mechanical dried Control, D Mechanical Dried Treatment)

The findings revealed significant differences in solar and mechanically dried duck meat balls in water activity and TBA values. The microbiological quality in terms of TPC, Yeast and Moulds was within the permissible limit. However, after 60 days of storage periods in aerobic packaging the growth for TPC and yeast and mould have emerged.

Finally it is concluded that the Solar and mechanically dried duck meat balls could be developed by adding Black eyed bean flour and phyto-ingredients that are safe from the point of microbiological, physicochemical quality and organoleptically acceptable through sensory evaluation.

\section{Acknowledgement}

The authors are thankful to department of livestock products technology, F/O Veterinary and Animal Sciences, West Bengal University of Animal and Fisheries Sciences, Kolkata for funding the ph.D research work and the authors have no objection/conflict of interest in publishing this peer review article

\section{References}

APHA (1984). Compendium of Methods for the microbiological examination of foods, 2 nd Ed. M.L. Speck, American Public Health Association, Washington, D.C.

Attmann, H.J.; Grunov, W.; Mohr, U.; Richterreichhelm, M. B.; Wester, P. W. (1986). Effects of BHA and related phenols 
on the fore stomach of rats. Food Chem. Toxicol. 24: 1183-1188.

Bhattacharyya, D., Sinhamahapatra, M. and Biswas, S. (2007). Preparation of sausage from spent duck an acceptability study. International Journal of Food Science and Technology, (42), 24-29.

Biswas, S., Chakraborty, A., Patra, G. and Dhargupta, A.(2011).Quality and acceptability of duck patties stored at ambient and refrigeration temperature. International Journal of Livestock Production Vol. 1(1), pp. 1- 6, January (2011).

DADF. (2012). 19th Quinquennial Livestock Census, Ministry of Agriculture, Department of Animal Husbandry Dairying and Fisheries.

De, P.N.(2001). A study on the quality of spent Emu meat with special reference to physico-chemical characters. M.V.Sc., Thesis submitted to WBUAFS, Kolkata,W.B.

Decker, E. A.; Mei, L. (1996). Antioxidants mechanisms and applications in muscle foods, In: Proceedings of the Reciprocal Meat Conference. Pp: 64-72.

FAO.2001.State of the World's Forests 2001. Rome. ftp.fao.org/docrep/fao/003/y0900e/.

Hotchkiss, H. J. and Potter, N. J. (1995). Heat Preservation and Processing. Food Science, 5th Edn. New York. Pp: 261-265.

Illayabharathi, D et al., 2012. Shelf-life of spent chicken sausage and its organoleptic qualities. Tamilnadu Journal of Veterinary and Animal Sciences, 8 (2), 60-67.

Ingham, S.C.; DeVita, M.D.; Wadhera, R.K.; Fanslau, M.A. and Buege, D.R. (2002). Evaltiation of small- scale hot-water postpackaging pasteurization treatments for destruction of Listeria monocytogenes on ready-to-eat beef snack sticks and natural casing wieners. Meat Sci. 74: 65 5-660.

Juntachote, T.; Berghofer, E.; Siebenhandi, S; Bauer, F. (2006). The oxidative properties of holy basil and Galangal in cooked ground beef. Meat Sci. 72: 446-456.

Nam, C.K.; Kim, H.C.; Cha, J. and Yirn, D.G. (2016). The Quality Characteristics and Antioxidant Propjties of Sun-dried Venison Jerky with Green Tea Powder during Storage. Korean J. Food Sci. 36: 626-634.

Naveena, B. M.; Sen, A.R.; Vaithiyanathan, S.; Babji, Y.; Kondaiah, N. (2008). Comparative efficacy of pomegranate juice, pomegranate rind powder extract and BHT as antioxidants in cooked chicken patties. Meat Sci. 80: 304-308.

Nunez de Gonzalez, -M Hafley, B.S.; Boleman, R.M.; Miller, R.K.; Rhee, K.S.; Keeton, J.T. (2005). Antioxidant properties of plum concentrates and powder in precooked roast beef to reduce lipid oxidation Meat Sci 80:997-1004

Rababah, T. M.; Hettiarachchy, N. S.; Horax, R. (2004). Total phenolics and antioxidant activities of fenugreek, green tea, black tea, grape seed, ginger, rosemary, gotu kola and ginkgo extracts, vitamin $\mathrm{E}$ and turtbutyl hydroquinone. $J$.Agric. Food Chem. 52:5183-5186.

Sekretar, S.; Schmidt, S.; Vjdak, M.; Zahradnikova, L.; Annus, J. (2004). Antioxidative and antimicrobial effects of some natural extracts in lard. Czech J. Food Sci. b 22:215-2 18

Stagnitta, P. V.; Micalizzi, B. and de Guzman, A. M. 5. (2006). Prevalence of some bacteria, yeasts and molds in meat foods in San Luis, Argentina. Cent. Eur. J. Pubi Health. 4:141-144.

Warris, P. D. (2006). Meat Science-An introductory test. 1st Edn. CABI Publishing. Wallingford, U.K.

\section{How to cite this article:}

Bhaskar. O. N., S. Biswas, S. Bano and Bhattacharya. D. 2020. Effect of Drying Methods on Value Added Duck Meat Balls. Int.J.Curr.Microbiol.App.Sci. 9(03): 1534-1539. doi: https://doi.org/10.20546/ijcmas.2020.903.179 